\title{
Extending lactation in pasture-based dairy cows. II: Effect of genetic strain and diet on plasma hormone and metabolite concentrations
}

\author{
J. K. Kay, ${ }^{1}$ C. V. C. Phyn, J. R. Roche, and E. S. Kolver ${ }^{2}$ \\ DairyNZ Ltd., Private Bag 3221, Hamilton, 3240, New Zealand
}

\section{ABSTRACT}

Fifty-six genetically divergent New Zealand and North American Holstein-Friesian (HF) cows grazed pasture, and were offered 0,3 , or $6 \mathrm{~kg}$ of concentrate $\mathrm{DM} /$ cow per day for an extended lactation $(605 \pm 8.3$ $\mathrm{d}$ in milk; mean \pm standard error of the mean). Weekly blood samples collected from individual cows from wk 1 to 10 postpartum (early lactation), and from wk 47 to 63 postpartum (extended lactation) were analyzed for nonesterified fatty acids (NEFA), glucose, insulin, leptin, growth hormone $(\mathrm{GH})$, insulin-like growth factor-I (IGF-I), calcium, and urea. During early lactation, NEFA and GH concentrations were greater and IGF-I concentrations were less, and increased at a slower rate in North American HF. During this 10-wk period, there were no strain effects on plasma glucose, leptin, insulin, or calcium. During the extended lactation period, North American HF had greater NEFA and GH concentrations; there were strain $\times$ diet interactions for insulin and leptin, and a tendency for a strain $\times$ diet interaction for glucose. These interactions were primarily due to greater plasma insulin, leptin, and glucose concentrations in the New Zealand HF fed $6 \mathrm{~kg}$ of concentrate $\mathrm{DM} /$ cow per day, a result of excessive body condition in this treatment. In this period, there was no strain effect on plasma IGF-I, calcium, or urea concentration. During early lactation, there was a linear increase in glucose and IGF-I, and a linear decrease in GH and urea with increasing concentrate in the diet. However, plasma calcium, NEFA, insulin, and leptin remained unchanged. During the extended lactation period, there was an effect of feed supplementation on GH and urea, which decreased linearly with increasing concentrate in the diet. There was, however, no supplementation effect on NEFA, calcium, or IGF-I. These data indicate potential strain differences in recoupling of the somatotropic axis, insulin resistance, and energy partition-

\footnotetext{
Received December 15, 2008.

Accepted April 21, 2009.

${ }^{1}$ Corresponding author: jane.kay@dairynz.co.nz

${ }^{2}$ Present address: Synlait Ltd., 1028 Heslerton Road, RD13, Rakaia, New Zealand.
}

ing, and may help explain the physiology behind the previously reported greater milk production and body condition score loss in North American HF. The results have implications for breeding and diet management during an extended lactation.

Key words: extended lactation, pasture, hormone, metabolite

\section{INTRODUCTION}

Seasonal calving patterns or 12-mo intercalving intervals are used in pasture-based dairy systems to ensure that pasture availability matches nutrient demand and milk production, thereby maximizing profitability (Dillon et al., 1995, 2005). Since the 1970s, semen from North American (NA) Holstein Friesian (HF) sires has been introduced into herds in many pasture-based dairy systems to increase individual cow milk production (Harris and Kolver, 2001; Roche et al., 2006). Compared with New Zealand (NZ) HF, NA HF produce more milk and undergo increased lipolysis during early lactation to support their greater milk production (Roche et al., 2006; McCarthy et al., 2007). This results in an increased severity and duration of negative energy balance, both of which adversely affect reproductive performance (Canfield and Butler, 1990; Drackley, 1999; Horan et al., 2005; Roche et al., 2007).

In a seasonal calving system, the adverse affect of negative energy balance on reproduction is exaggerated, because the planned start of mating to ensure a 12-mo calving pattern coincides with peak lactation, when many cows are still in negative energy balance. A prolonged breeding period reduces milk production efficiency; therefore, cows that fail to conceive during the prescribed breeding period are culled to maintain a compact seasonal calving pattern (Harris and Kolver, 2001). This has resulted in significant cow wastage in pasture-based systems, with NA HF having an $11 \%$ lower chance of survival from the first to second lactation and a $27 \%$ lower chance of surviving to their fifth lactation than NZ HF (Harris and Kolver, 2001). Thus, the concept of an extended lactation or 24-mo intercalving interval has been proposed as a management strategy to potentially improve reproduction and increase 
cow survival (Knight, 1998; Kolver et al., 2007) while continuing to match feed supply with energy demand in a pasture-based system.

Milking cows for an extended lactation in a pasturebased dairy system is feasible; however, there is considerable between-cow variation in their ability to maintain milk production for an extended period, with some genetic strain and diet combinations demonstrating no loss of annualized milk production and other combinations resulting in reduced milk production (Butler et al., 2006; Auldist et al., 2007; Kolver et al., 2007).

Compared with NZ HF, NA HF are reported to produce more milk during an extended lactation, especially when fed increasing amounts of supplements (Kolver et al., 2007). There are however, few published data detailing the metabolic status of genetically divergent animals offered different levels of supplementation during a pasture-based extended lactation. Hormone and metabolite data that reflect the energetic and metabolic status of the dairy cow will increase understanding of the physiology underpinning the variation in milk production, reproduction, and BCS change (Kolver et al., 2007). The objectives of the current study were to determine the effect of divergent genetic HF strains (and therefore different milk yields) offered varying levels of a concentrate supplement on plasma hormone and metabolite concentrations in early lactation (wk 1 to 10 postpartum), and during the corresponding period in the second season of an extended lactation (wk 47 to 63 postpartum).

\section{MATERIALS AND METHODS}

\section{Experimental Design}

The experimental design, cow selection, feeding and management practices, breeding program, and production measurements from the present study have been described previously (Kolver et al., 2007). Briefly, 56 mixed-age $\mathrm{HF}$ of predominantly $(>87.5 \%) \mathrm{NA}$ or $\mathrm{NZ}$ ancestry grazed a generous allowance of pasture $(50 \mathrm{~kg}$ of $\mathrm{DM} /$ cow per day) as 1 herd, and were individually offered 0,3 , or $6 \mathrm{~kg}$ of $\mathrm{DM} / \mathrm{cow}$ per day of a pelleted concentrate supplement for an extended lactation.

\section{Animal Management}

Cows were allocated to treatments based on genetic strain ancestry and breeding worth (the NZ genetic evaluation system), and within genetic strain, treatments were balanced for $\mathrm{BW}$ and expected calving date. The number of cows analyzed per treatment were NZ0 (NZ $\mathrm{HF}$ fed $0 \mathrm{~kg} / \mathrm{d}$ of concentrate DM; $\mathrm{n}=10), \mathrm{NZ3}(\mathrm{NZ}$ HF fed $3 \mathrm{~kg} / \mathrm{d}$ of concentrate DM; $\mathrm{n}=9$ ), NZ6 (NZ HF fed $6 \mathrm{~kg} / \mathrm{d}$ of concentrate DM; n = 10), NA0 (NA HF fed $0 \mathrm{~kg} / \mathrm{d}$ of concentrate DM; $\mathrm{n}=8$ ), NA3 (NA HF fed $3 \mathrm{~kg} / \mathrm{d}$ of concentrate DM; $\mathrm{n}=9$ ), and NA6 (NA HF fed $6 \mathrm{~kg} / \mathrm{d}$ of concentrate DM; $\mathrm{n}=10$ ). The NA and $\mathrm{NZ}$ ancestries are based on 3-generation pedigrees, and common sires were represented in each treatment (NZ0, 7 sires; NZ3, 6 sires; NZ6, 5 sires; NA0, 5 sires; NA3, 7 sires; NA6, 9 sires). The NA HF were either imported as embryos from the United States and the Netherlands in 1996 by Holland Genetics Ltd. (Arnhem, the Netherlands) for Livestock Improvement New Zealand Corp. (Hamilton, New Zealand), as part of their sire-proving scheme, or were direct descendents of these embryos. Progeny of the embryo imports were sold to commercial farms, and then purchased by DairyNZ before their first parturition. Details on breeding worth, breeding value, age, and calving date have been described previously (Kolver et al., 2007).

To provide reproductive data from a normal 12-mo calving interval, cows were bred at approximately 82 d postpartum. To establish the 24-mo calving interval, pregnancies were terminated at approximately $112 \mathrm{~d}$ postpartum and a subsequent 12 -wk breeding period began at $451 \mathrm{~d}$ postpartum. Drying-off decisions were based on the method of Macdonald et al. (2005), and individual cows were dried off if milk production declined below $5 \mathrm{~kg}$ of milk/d for 2 consecutive weeks. The final dry-off date was $52 \mathrm{~d}$ before planned start of calving (Kolver et al., 2007).

\section{Dietary Management}

All cows were offered a common pasture allowance (50 kg of DM/d; measured to ground level) and concentrate supplement was fed in equal portions at the a.m. and p.m. milkings from June 2003 to May 2005. Diets were designed to meet or exceed predicted requirements (NRC, 2001), and $6 \mathrm{~kg}$ of DM concentrate/d (14.0 MJ of $\mathrm{ME} / \mathrm{kg}$ of DM; $11.5 \% \mathrm{CP} ; 9.5 \% \mathrm{NDF} ; 4.2 \% \mathrm{ADF}$ ) was considered the most supplement that could be fed with high-quality pasture (11.9 MJ of $\mathrm{ME} / \mathrm{kg}$ of DM; $23.5 \% \mathrm{CP} ; 41.5 \% \mathrm{NDF} ; 22.1 \% \mathrm{ADF})$ and not result in either fiber or protein deficiencies. On a DM basis, the pasture sward consisted of approximately $68 \%$ perennial ryegrass leaf (Lolium perenne L.), $14 \%$ perennial ryegrass stem, $12 \%$ white clover (Trifolium repens L.), $1 \%$ weeds, and $5 \%$ dead material. To maintain pasture residual targets, grass silage (11.1 MJ of $\mathrm{ME} / \mathrm{kg}$ of DM, $18.2 \%$ CP; $47.6 \%$ NDF; $32.1 \%$ ADF) was fed from August to September (2003, $3.6 \mathrm{~kg}$ of DM/d for $37 \mathrm{~d}$; $2004,5.9 \mathrm{~kg}$ of DM/d for $53 \mathrm{~d}$ ) and from April to July 2004 (4 kg of DM/d for $109 \mathrm{~d}$ ). Details on concentrate feeding, pasture rotation length, pasture allocation, and mineral supplementation have been described previously (Kolver et al., 2007). 


\section{Measurements}

Individual milk yields were recorded at each milking (Westfalia Surge, Oelde, Germany), and milk composition was determined weekly by Fourier-transform infrared spectroscopy (FT120, Foss Electric, Hillerød, Denmark) on individual p.m. and a.m. samples. Individual $\mathrm{BW}$ was recorded weekly, and BCS (1 to 10 scale; Roche et al., 2004) was assessed weekly during the early (wk 1 to 10 postpartum) and extended (wk 47 to 63 postpartum) lactation periods, and every $2 \mathrm{wk}$ for the remainder of the lactation. Details of pasture and concentrate sampling and analysis have been described previously (Kolver et al., 2007).

Blood samples $(\sim 10 \mathrm{~mL})$ were collected on $1 \mathrm{~d}$ each week immediately after the a.m. milking for the first 10 wk postpartum (early lactation) and from wk 47 to 63 (extended lactation). Samples were collected from the coccygeal vein of each cow into two $10-\mathrm{mL}$ evacuated blood tubes (140 IU of sodium heparin and $0.1117 \mathrm{~mL}$ of $15 \% \mathrm{~K}_{3}$ EDTA; Export Lodge, Te Awamatu, New Zealand). Samples were placed on ice and centrifuged at $1,120 \times g$ for $10 \mathrm{~min}$. Plasma was harvested and stored at $-20^{\circ} \mathrm{C}$ while awaiting subsequent analyses for insulin, growth hormone (GH), IGF-I, leptin, glucose, NEFA, calcium, and urea. The NEFA (colorimetric method), glucose (hexokinase method), calcium (ocresolphthalein complexone), and urea (urease method) analyses were performed on a Hitachi 717 analyzer (Roche, Basel, Switzerland) at $30^{\circ} \mathrm{C}$ by Gribbles Laboratory (Hamilton, NZ). The inter- and intraassay coefficients of variation were $<2 \%$ for all assays. Plasma insulin (Hales and Randle, 1963), GH (Downing et al., 1995), IGF-I (Gluckman et al., 1983), and leptin (Blache et al., 2000) were measured in duplicate by a double-antibody RIA, with inter- and intraassay coefficients of variation of $<16 \%$.

\section{Statistical Analysis}

Weekly data were averaged for each period (early lactation: wk 1 to 10 postpartum; extended lactation: wk 47 to 63 postpartum) and analyzed using the REML procedure of GenStat (version 3.2), with a model that included genetic strain, diet (linear and quadratic contrasts), and strain $\times$ diet interactions as fixed effects, and sire and cow as random effects.

To investigate the temporal pattern of hormones and metabolites during the early and extended lactation periods, repeated measurements through time were modeled using splines within the linear mixed model framework described by Verbyla et al. (1999). Genetic strain, diet, the linear trend of time, and their interactions were included as fixed effects, and cow, the linear trend of time within cow, spline, and the interaction of genetic strain and diet with spline were included as random effects. Restricted maximum likelihood in GenStat 10 was used to fit these models. Mean weekly data points with fitted splines are presented in Figures 1, 2, 3 , and 4; however, for clarity only the fitted splines have been presented in Figure 5 Differences were considered significant at $P<0.05$, and a trend was declared at $P<0.10$. Significance levels for the genetic strain $\times$ diet $_{\text {Quadratic }}$ interaction are not presented because none was significant.

\section{RESULTS}

Milk production, BW, BCS, udder health, and reproductive data from this experiment have been reported previously (Lacy-Hulbert et al., 2006; Kolver et al., 2007). Briefly, NA HF produced $35 \%$ more milk, $24 \%$ more milk fat, $25 \%$ more milk protein, and at drying off had 1.9 units less BCS than NZ HF. Increasing the level of concentrate offered resulted in a linear increase in milk yield and BCS; however, there were strain $\times$ diet interactions for milk and protein yield, with strain differences being greatest at the highest level of supplementation (Kolver et al., 2007). Although reproductive indices improved in the NA HF when mated at 451 d postpartum (compared with 82 d postpartum), the final nonpregnancy rate remained greater $(P<0.05)$ for NA HF mated at $451 \mathrm{~d}$ postpartum compared with NZ HF (30 vs. 3\%, respectively; Kolver et al., 2007). With regard to udder health, average SCC was 3-fold greater in the second season compared with the first season of the extended lactation, and SCC were greater in NZ compared with NA HF (Lacy-Hulbert et al., 2006). However, the SCC elevation, with advancing lactation, occurred regardless of the infection status of the udder. Incidences of clinical mastitis were greater in NA HF in the first season (59 vs. $27 \%$ for NA and NZ HF, respectively) but did not differ between strains in the second season (18 and 20\% for NA and NZ HF, respectively (Lacy-Hulbert et al., 2006).

\section{Genetic Strain}

Early Lactation. In early lactation (wk 1 to 10 postpartum), NA HF had greater $(P<0.05)$ plasma NEFA and GH, and less $(P<0.05)$ IGF-I compared with NZ HF (Table 1). Plasma IGF-I concentrations increased with weeks postpartum, and this effect was modified by strain (Figure 1A), with plasma IGF-I concentration increasing at a slower rate in NA HF $(P<$ 0.05; Figure 1A). Plasma GH concentration was greater $(P<0.01)$ in NA HF at the initiation of sampling (wk 1 postpartum) and remained greater during the 10 -wk 
Table 1. Plasma hormone and metabolite concentrations in New Zealand (NZ) and North American (NA) strains of Holstein-Friesian (HF) cows grazing pasture and fed 0,3 , or $6 \mathrm{~kg}$ of concentrate $\mathrm{DM} /$ cow per day during early lactation (wk 1 to 10 postpartum)

\begin{tabular}{|c|c|c|c|c|c|c|c|c|c|c|}
\hline \multirow[b]{2}{*}{ Item } & \multicolumn{6}{|c|}{ Treatment $^{1}$} & \multirow[b]{2}{*}{$\mathrm{SED}^{2}$} & \multicolumn{3}{|c|}{$P$-value ${ }^{3}$} \\
\hline & NZ0 & NZ3 & NZ6 & NA0 & NA3 & NA6 & & Strain & $\operatorname{Diet}_{\mathrm{L}}$ & $\mathrm{S} \times \mathrm{D}_{\mathrm{L}}$ \\
\hline Urea $(\mathrm{mmol} / \mathrm{L})$ & 6.29 & 5.40 & 4.87 & 6.11 & 5.06 & 4.45 & 0.50 & 0.32 & $<0.01$ & 0.93 \\
\hline NEFA (mmol/L) & 0.64 & 0.49 & 0.59 & 0.77 & 0.71 & 0.80 & 0.11 & $<0.05$ & 0.78 & 0.75 \\
\hline Insulin $(\mu \mathrm{U} / \mathrm{mL})$ & 6.64 & 8.77 & 7.23 & 6.41 & 7.12 & 9.24 & 1.69 & 1.00 & 0.15 & 0.29 \\
\hline Glucose $(\mathrm{mmol} / \mathrm{L})$ & 3.23 & 3.44 & 3.43 & 3.09 & 3.30 & 3.45 & 0.14 & 0.34 & $<0.01$ & 0.67 \\
\hline Growth hormone (ng/mL) & 9.01 & 7.68 & 5.91 & 11.85 & 12.23 & 7.20 & 1.64 & 0.02 & $<0.01$ & 0.36 \\
\hline
\end{tabular}

${ }^{1}$ Treatment: NZ0 $=$ NZ HF fed $0 \mathrm{~kg} / \mathrm{d}$ of concentrate DM; NZ3 = NZ HF fed $3 \mathrm{~kg} / \mathrm{d}$ of concentrate DM; NZ6 = NZ HF fed $6 \mathrm{~kg} / \mathrm{d}$ of concentrate $\mathrm{DM} ; \mathrm{NA} 0=\mathrm{NA} H F$ fed $0 \mathrm{~kg} / \mathrm{d}$ of concentrate DM; NA3 = NA HF fed $3 \mathrm{~kg} / \mathrm{d}$ of concentrate DM; NA6 = NA HF fed $6 \mathrm{~kg} / \mathrm{d}$ of concentrate DM.

${ }^{2}$ Standard error of the difference.

${ }^{3} \mathrm{~L}=$ linear contrast; $\mathrm{S} \times \mathrm{D}_{\mathrm{L}}=$ strain $\times \operatorname{diet}_{\mathrm{L}}$ interaction.

period (Figure 1B). During early lactation, there was no strain effect on calcium, urea, leptin, insulin, or glucose concentration (Table 1), and there was no strain $\times$ diet interaction for any of the hormones or metabolites measured (Table 1).

Extended Lactation. In the extended lactation period (wk 47 to 63 postpartum), plasma NEFA and GH concentrations were greater $(P<0.05)$ in NA HF, but there was no strain effect on plasma IGF-I, calcium, or urea (Table 2). The temporal IGF-I pattern was not affected by strain (Figure 2A); however, GH concentrations remained greater $(P<0.05)$ in the NA HF throughout the extended lactation period (Figure 2B). There was a strain $\times$ diet interaction for insulin and leptin, and a tendency $(P=0.09)$ for a strain $\times$ diet interaction for glucose (Table 2). These interactions were primarily due to elevated plasma glucose, insulin, and leptin concentrations throughout the extended lac- tation period in NZ HF consuming $6 \mathrm{~kg}$ of concentrate DM/d (Figure 3A, 3B, and 3C, respectively).

\section{Diet}

Early Lactation. During early lactation, plasma IGF-I and glucose concentrations increased linearly $(P<0.05)$, whereas urea and $\mathrm{GH}$ concentrations decreased linearly $(P<0.01)$ with an increasing amount of concentrate in the diet (Table 1). During this period, however, concentrate supplementation did not alter plasma calcium, NEFA, insulin, or leptin concentration (Table 1). Spline modeling demonstrated no effect of supplementation on the initial IGF-I concentration (wk 1 postpartum), or on the rate of increase during the 10-wk period (Figure 4A). Plasma GH concentration was similar at initiation of sampling (wk 1 postpartum; Figure 4B); however, there was a supplementation ef-

Table 2. Plasma hormone and metabolite concentrations in New Zealand (NZ) and North American (NA) strains of Holstein-Friesian (HF) cows grazing pasture and fed 0,3 , or $6 \mathrm{~kg}$ of concentrate DM/cow per day during extended lactation (wk 47 to 63 postpartum)

\begin{tabular}{|c|c|c|c|c|c|c|c|c|c|c|}
\hline \multirow[b]{2}{*}{ Item } & \multicolumn{6}{|c|}{ Treatment $^{1}$} & \multirow[b]{2}{*}{$\mathrm{SED}^{2}$} & \multicolumn{3}{|c|}{$P$-value ${ }^{3}$} \\
\hline & NZ0 & NZ3 & NZ6 & NA0 & NA3 & NA6 & & Strain & $\operatorname{Diet}_{\mathrm{L}}$ & $\mathrm{S} \times \mathrm{D}_{\mathrm{L}}$ \\
\hline Urea $(\mathrm{mmol} / \mathrm{L})$ & 6.06 & 5.53 & 5.01 & 5.93 & 5.39 & 4.63 & 0.26 & 0.26 & $<0.01$ & 0.61 \\
\hline $\mathrm{NEFA}(\mathrm{mmol} / \mathrm{L})$ & 0.19 & 0.16 & 0.16 & 0.21 & 0.18 & 0.19 & 0.02 & $<0.05$ & 0.18 & 0.95 \\
\hline Insulin $(\mu \mathrm{U} / \mathrm{mL})$ & 4.35 & 5.02 & 7.86 & 4.73 & 4.46 & 4.83 & 0.97 & 0.07 & $<0.01$ & $<0.05$ \\
\hline Glucose (mmol/L) & 3.93 & 3.85 & 4.12 & 3.89 & 3.79 & 3.86 & 0.08 & $<0.05$ & 0.12 & 0.09 \\
\hline Growth hormone (ng/mL) & 1.77 & 1.52 & 1.33 & 2.62 & 2.71 & 1.63 & 0.31 & $<0.01$ & $<0.01$ & 0.14 \\
\hline
\end{tabular}

${ }^{1}$ Treatment: NZ0 = NZ HF fed $0 \mathrm{~kg} / \mathrm{d}$ of concentrate DM; NZ3 = NZ HF fed $3 \mathrm{~kg} / \mathrm{d}$ of concentrate DM; NZ6 = NZ HF fed $6 \mathrm{~kg} / \mathrm{d}$ of concentrate $\mathrm{DM} ; \mathrm{NA} 0=\mathrm{NA}$ HF fed $0 \mathrm{~kg} / \mathrm{d}$ of concentrate DM; NA3 = NA HF fed $3 \mathrm{~kg} / \mathrm{d}$ of concentrate DM; NA6 = NA HF fed $6 \mathrm{~kg} / \mathrm{d}$ of concentrate DM.

${ }^{2}$ Standard error of the difference.

${ }^{3} \mathrm{~L}=$ linear contrast; $\mathrm{S} \times \mathrm{D}_{\mathrm{L}}=$ strain $\times \operatorname{diet}_{\mathrm{L}}$ interaction. 

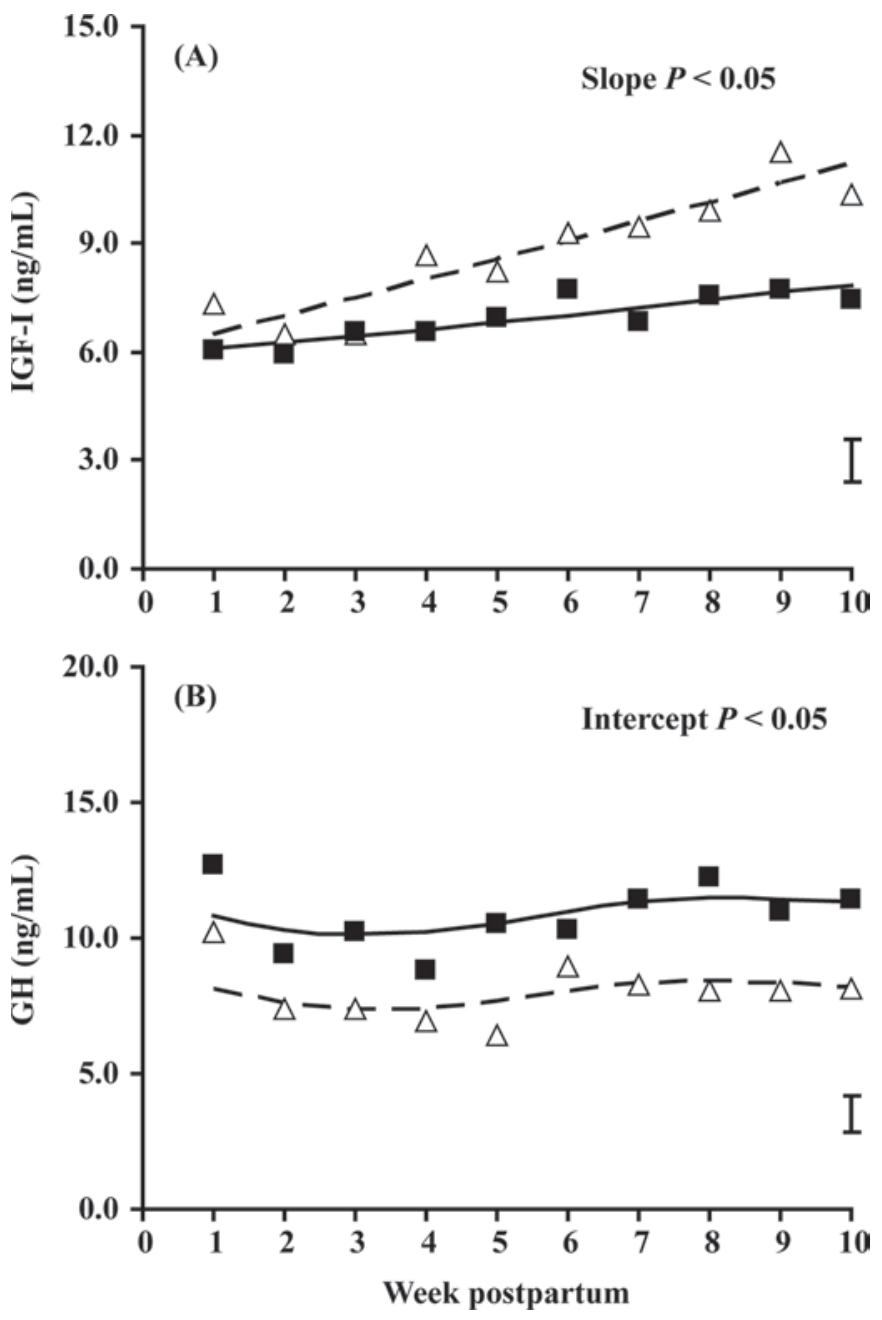

Figure 1. A) Insulin-like growth factor-I and B) growth hormone (GH) concentrations (weekly means and fitted splines) during early lactation (wk 1 to 10 postpartum) of New Zealand ( $\Delta$, dashed line) and North American ( $\mathbf{\square}$, solid line) Holstein-Friesians grazing pasture and offered 0,3 , or $6 \mathrm{~kg}$ of concentrate $\mathrm{DM} /$ cow per day during a 605 \pm 8.3 -d lactation (mean \pm SEM). The average standard error of the difference is represented by the error bar, and $P$-values for the intercept, slope, spline, and interactions are presented only if significant.

fect on the slope of GH concentration throughout the extended lactation period, with $\mathrm{GH}$ concentration of the $0 \mathrm{~kg}$ of concentrate $\mathrm{DM} / \mathrm{d}$ treatment increasing over time compared with the 3 - and 6 -kg treatments.

Extended Lactation. During the extended lactation period, plasma urea and GH concentrations decreased linearly $(P<0.01)$ with increasing concentrate in the diet; however, there was no supplementation effect on plasma IGF-I, NEFA, or calcium concentration (Table 2 ), or on the temporal pattern of IGF-I concentration (Figure 5A). There was a supplementation effect on the initial GH concentration (wk 47 postpartum) and on the shape of the spline, with GH concentration less in the $6 \mathrm{~kg}$ of concentrate $\mathrm{DM} / \mathrm{d}$ treatment at the begin-
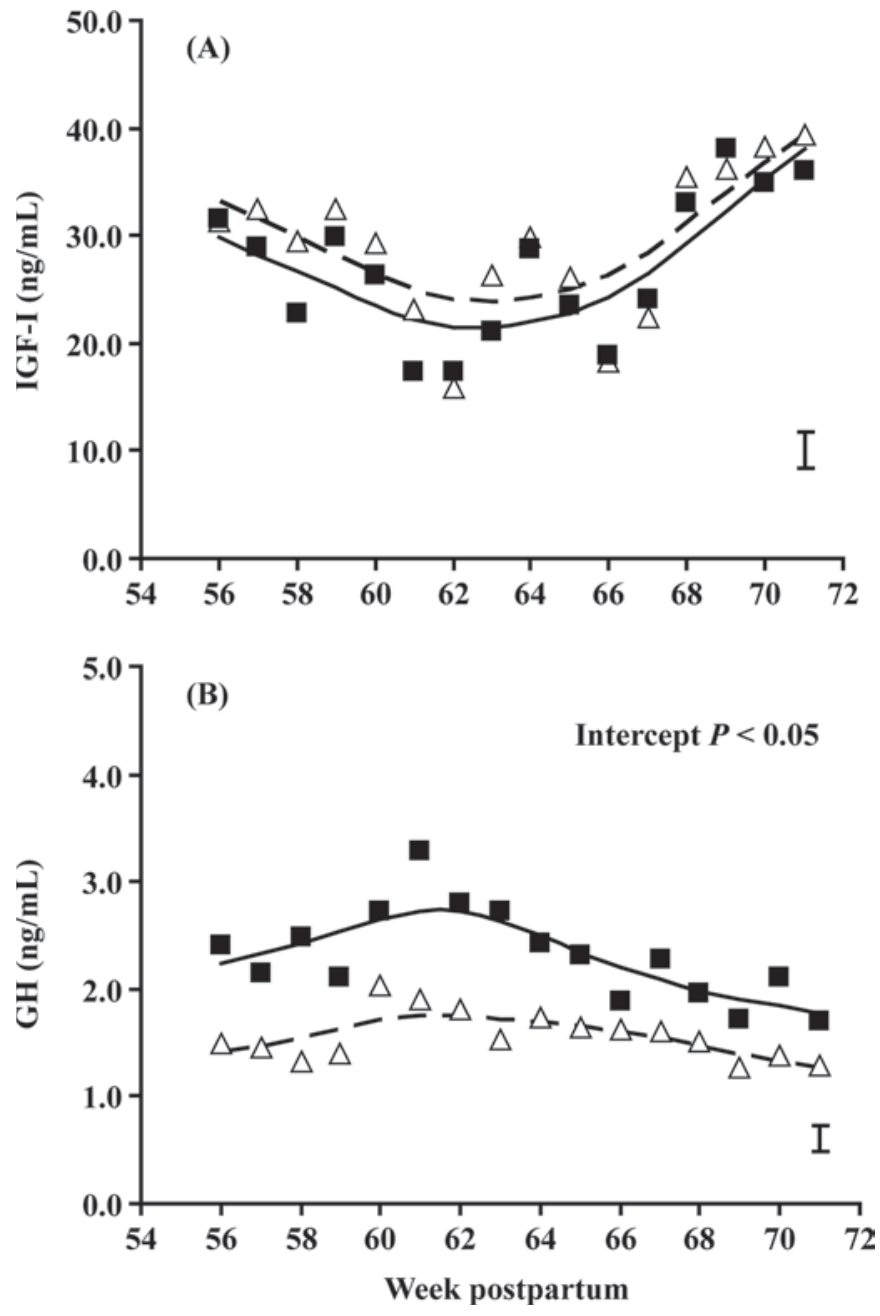

Figure 2. A) Insulin-like growth factor-I and B) growth hormone $(\mathrm{GH})$ concentrations (weekly means and fitted splines) during extended lactation (wk 47 to 63 postpartum) of New Zealand ( $\Delta$, dashed line) and North American (ם, solid line) Holstein-Friesians grazing pasture and offered 0,3 , or $6 \mathrm{~kg}$ of concentrate $\mathrm{DM} /$ cow per day during a $605 \pm 8.3$-d lactation (mean $\pm \mathrm{SEM}$ ). The average standard error of the difference is represented by the error bar, and $P$-values for the intercept, slope, spline, and interactions are presented only if significant.

ning of the extended lactation period and following a different temporal pattern compared with the 0- and $3-\mathrm{kg}$ treatments (Figure 5B).

\section{DISCUSSION}

Understanding the physiology regulating production, $\mathrm{BCS}$, and reproduction is paramount to obtain optimal genetics and management combinations for any dairy production system. This is the first study to report the effects of genetic strain and diet on plasma hormones and metabolites during an extended lactation in a pasture-based system. Data indicate a delayed recou- 

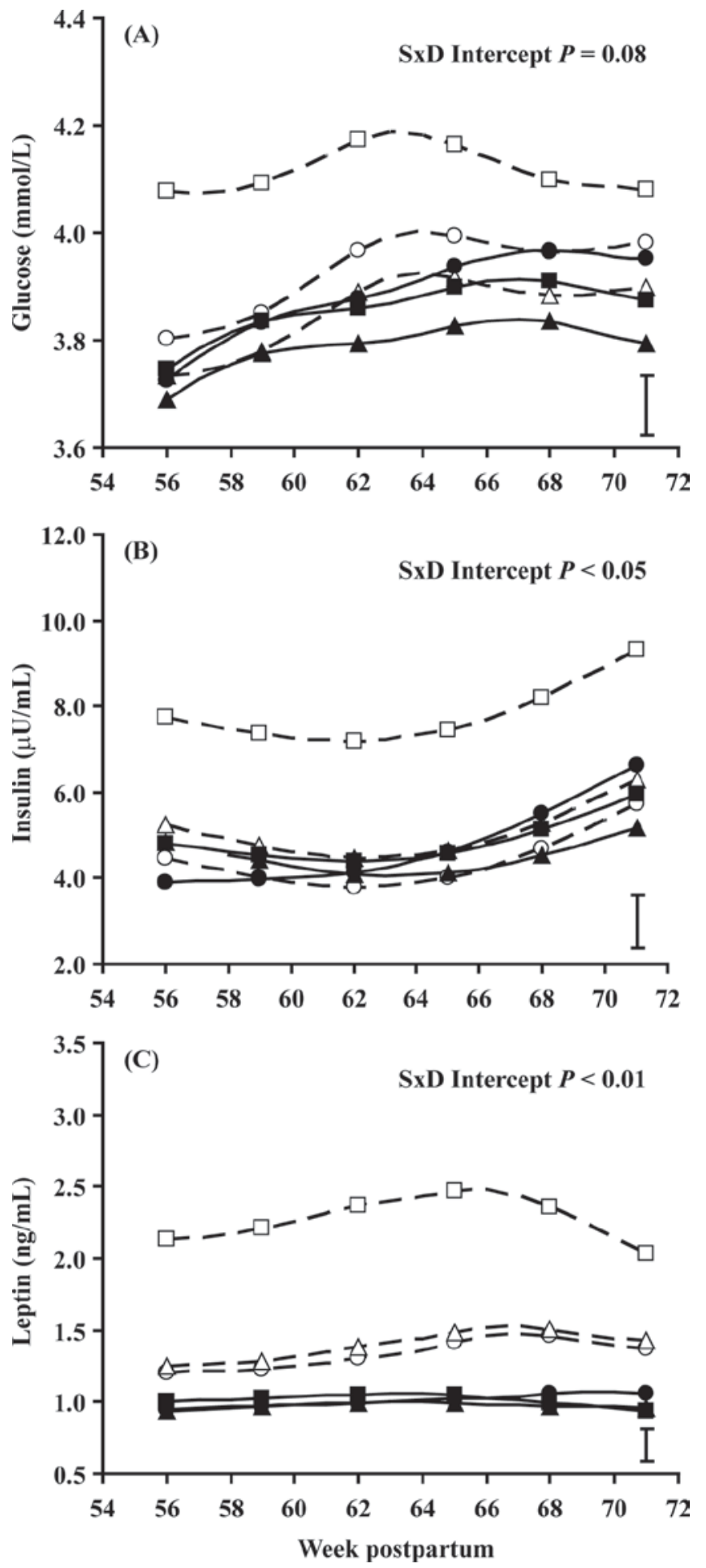

Figure 3. A) Glucose, B) insulin, and C) leptin concentrations (fitted splines) during extended lactation (wk 47 to 63 postpartum) of New Zealand (open symbols, dashed lines) and North American (closed symbols, solid lines) Holstein-Friesians grazing pasture and offered $0(\bigcirc, \bullet) 3(\Delta, \boldsymbol{\Delta})$, or $6(\square, \boldsymbol{\square}) \mathrm{kg}$ of concentrate $\mathrm{DM} /$ cow per day during a $605 \pm 8.3$-d lactation (mean \pm SEM). The average standard error of the difference is represented by the error bar, and $P$-values for the intercept, slope, spline, and interactions are presented only if significant. $\mathrm{S} \times \mathrm{D}=$ strain $\times$ diet interaction.
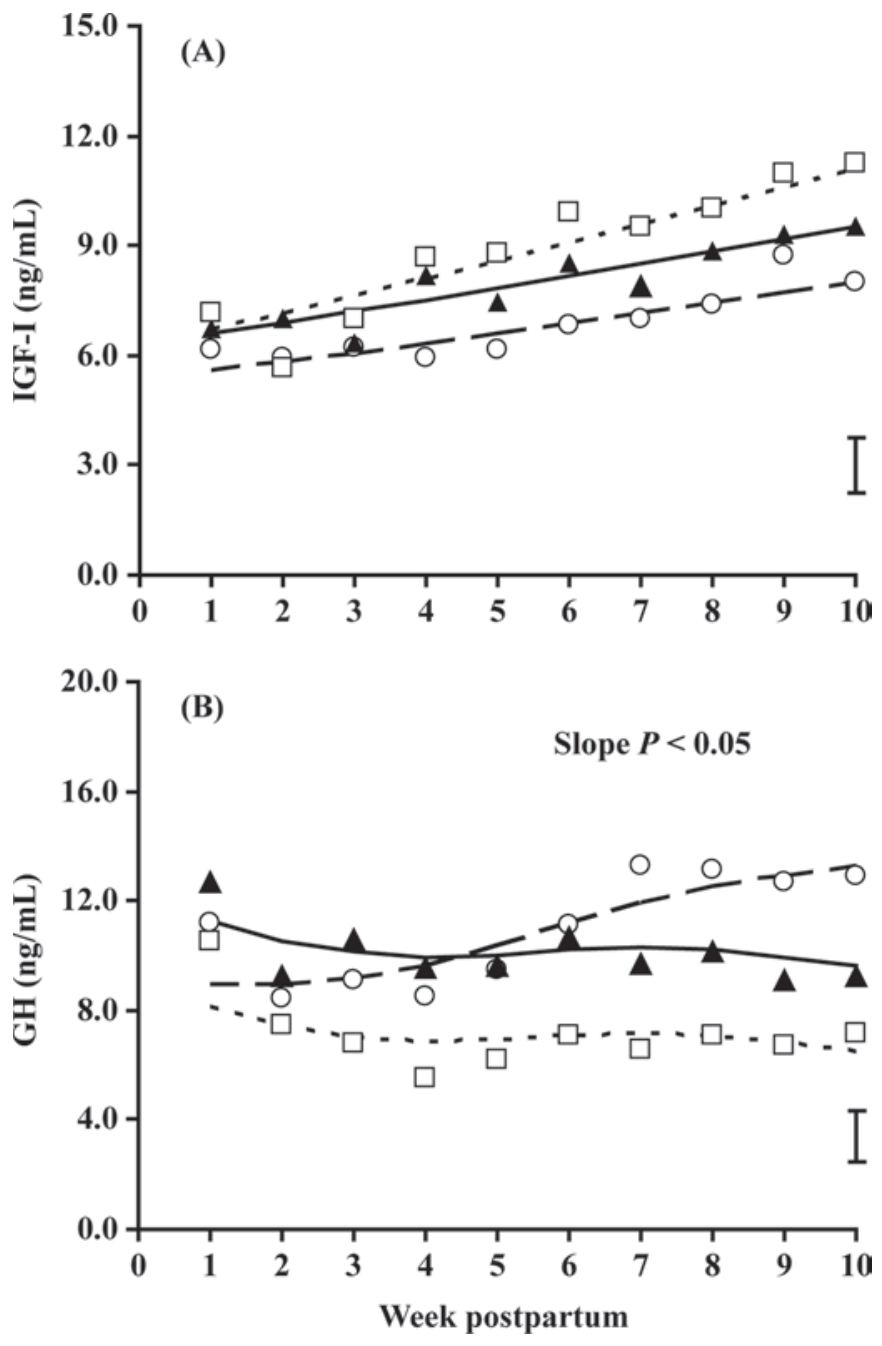

Figure 4. A) Insulin-like growth factor-I and B) growth hormone $(\mathrm{GH})$ concentrations (weekly means and fitted splines) during early lactation (wk 1 to 10 postpartum) of New Zealand and North American Holstein-Friesians grazing pasture and offered $0(\bigcirc$, dashed line), 3 ( $\mathbf{\Lambda}$, solid line), or 6 ( $\square$, dotted line) $\mathrm{kg}$ of concentrate DM/cow per day during a $605 \pm 8$.3-d lactation (mean \pm SEM). The average standard error of the difference is represented by the error bar, and $P$-values for the intercept, slope, spline, and interactions are presented only if significant.

pling of the somatotropic axis in the NA HF during early lactation (wk 1 to 10 postpartum), and a greater partitioning of energy toward body reserves (to the detriment of milk production; Kolver et al., 2007) in the NZ HF fed $6 \mathrm{~kg}$ of concentrate DM/cow per day in the extended lactation period (wk 47 to 63 postpartum).

\section{Genetic Strain}

Early Lactation. Uncoupling of the somatotropic axis in early lactation, whereby the liver fails to produce IGF-I in response to increased circulating GH, is typical of high-producing dairy cows (see reviews 

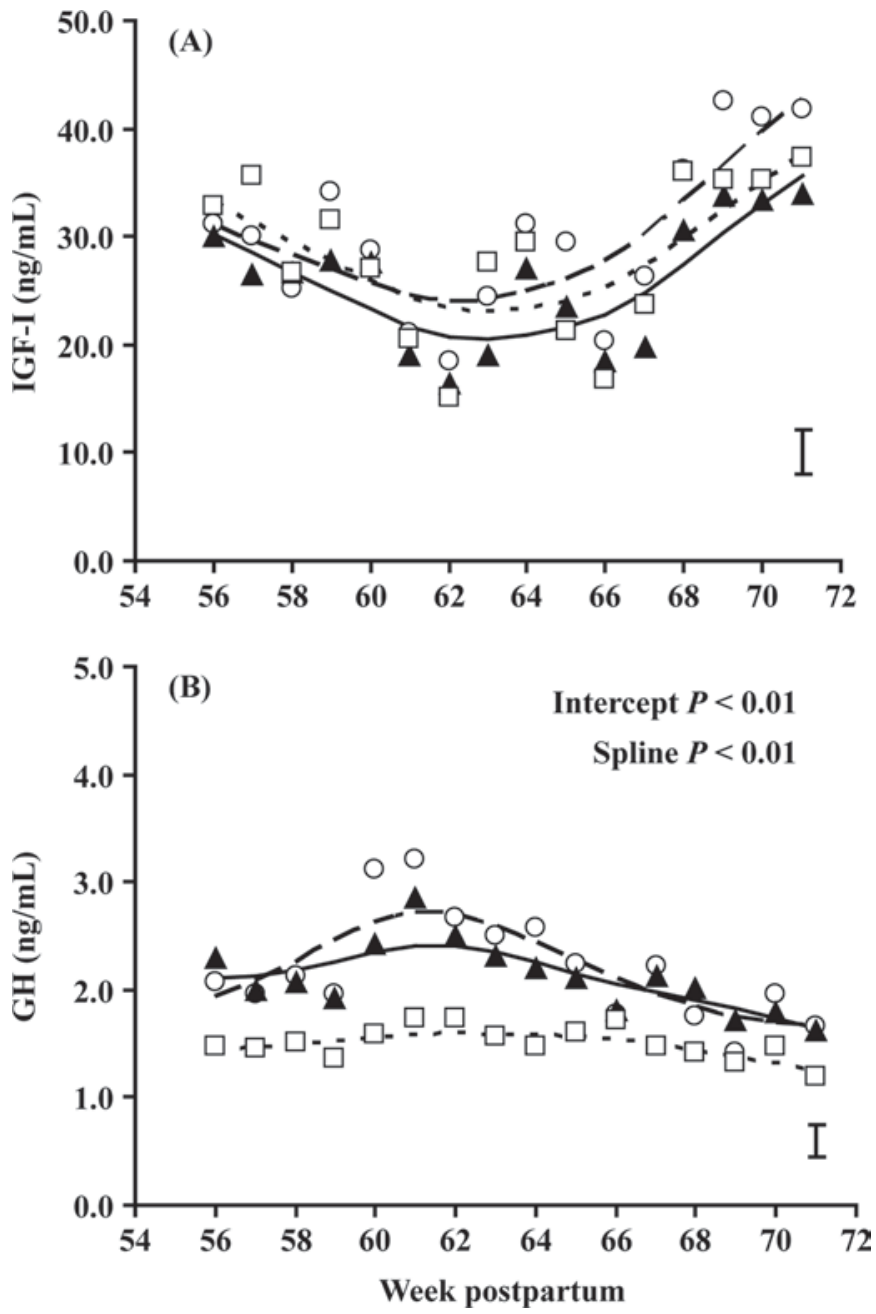

Figure 5. A) Insulin-like growth factor-I and B) growth hormone (GH) concentrations (weekly means and fitted splines) during extended lactation (wk 47 to 63 postpartum) of New Zealand and North American Holstein-Friesians grazing pasture and offered $0(\mathrm{O}$, dashed line), 3 ( $\mathbf{\Lambda}$, solid line), or 6 ( $\square$, dotted line) $\mathrm{kg}$ of concentrate DM/cow per day during a $605 \pm 8.3$-d lactation (mean \pm SEM). The average standard error of the difference is represented by the error bar, and $P$-values for the intercept, slope, spline, and interactions are presented only if significant.

by Bauman, 2000; Lucy et al., 2001). This is associated with reduced expression of the liver-specific $\mathrm{GH}$ receptor (GHR) transcript (GHR-1A), and decreased GHR abundance (Radcliff et al. 2003; Kim et al., 2004; Rhoads et al., 2007). In the present study, both NA and NZ HF had greater plasma GH concentrations and lower IGF-I concentrations in early lactation compared with the extended lactation period, indicating some degree of uncoupling of the somatotropic axis in both genetic strains postpartum. However, there was a genetic strain effect on IGF-I and GH concentrations, with NA HF having lower IGF-I and greater GH concentrations, indicating a greater degree of uncoupling. Spline mod- eling demonstrated that, in early lactation, there was a slower rate of increase in plasma IGF-I concentration in NA HF, despite the elevated GH concentration. This is consistent with a greater degree of uncoupling and a delayed (or slower) recoupling of the somatotropic axis in the NA HF. These data are consistent with those of Lucy et al. (2009) and Kolver et al. (2006), who reported a greater uncoupling and a delayed recoupling of the somatotropic axis in NA HF during the first $12 \mathrm{wk}$ postpartum, based on GH and IGF-I concentrations, and reduced liver GHR-1A mRNA expression.

Plasma IGF-I is the primary systemic negative feedback hormone for GH production (Etherton and Bauman, 1998; Le Roith et al., 2001), and decreased IGF-I concentration in NA HF likely contributes to the increased GH concentration in these animals, through reduced negative feedback. In addition, GH concentration may be greater in NA HF because of increased sensitivity to GH-releasing hormone, reduced clearance of $\mathrm{GH}$ from the blood, or a combination of these factors (Hart et al., 1978; Beerepoot et al., 1991; Knight et al., 2004; Weber et al., 2007). Because GH facilitates lipolysis and increases hepatic gluconeogenesis during early lactation (Etherton and Bauman, 1998), the greater GH concentration in NA HF is consistent with increased NEFA concentration (indicating increased lipolysis), greater loss of BCS, and greater milk production in NA HF during early lactation (Roche et al., 2006; Kolver et al., 2007; McCarthy et al., 2007).

Recoupling of the somatotropic axis postpartum is influenced by energetic status, insulin concentration, and degree of insulin resistance (Lucy et al., 2001; Butler et al., 2003; Rhoads et al., 2004; Radcliff et al., 2006). During early lactation, the dairy cow undergoes a period of increased insulin resistance to ensure that circulating glucose is utilized primarily by the mammary gland and not by extramammary tissue that contains insulin-dependent glucose transporters (Bauman and Currie, 1980). There was no genetic strain effect on insulin concentration in early lactation; however, NA HF demonstrated a greater degree and duration of uncoupling of the somatotropic axis (based on a lower IGF-I and a greater GH concentration), increased milk production, and BCS loss (Kolver et al., 2007), all of which indicate NA HF have greater insulin resistance in early lactation compared with NZ HF. This is consistent with the results of Chagas et al. (2009), who reported a greater degree of insulin resistance in NA HF after a glucose tolerance test in wk 5 postpartum, compared with NZ HF. These data support the hypothesis that NA HF are more efficient at partitioning nutrients to milk production rather than body reserves immediately postpartum. These physiological factors are likely detrimental to reproductive performance in a 
typical seasonal 300-d lactation (Chagas et al., 2007); however, they appear to be key factors in undergoing a successful extended lactation (Kay et al., 2007).

Extended Lactation. Genetic strain influenced GH concentration during the extended lactation period, and as reported previously (Knight et al., 2004; Weber et al., 2007), a positive relationship existed between genetic merit for milk yield and GH concentrations. During the extended lactation period, there was no strain effect on IGF-I concentration, and combined with BCS data (Kolver et al., 2007), this indicated all animals were in a positive energy balance with a recoupled somatotropic axis. Thus, it is unlikely that IGF-I feedback would be contributing to the greater GH concentration in the NA HF during the extended lactation period, and the strain effect was most likely due to reduced clearance of GH from the blood or increased sensitivity to GH-releasing hormone (Knight et al., 2004). Despite both strains being in a positive energy balance when mated at $451 \mathrm{~d}$ postpartum, reproductive performance was still compromised in NA HF (30 vs. 3\% nonpregnant in NA and NZ HF, respectively; Kolver et al., 2007), indicating that energy balance is not the only factor contributing to infertility problems in pasture-based NA HF (Chagas et al., 2007; Kolver et al., 2007).

\section{Diet}

Early Lactation. Data from the present study indicate a nutritional effect on postpartum recoupling of the somatotropic axis. In early lactation, IGF-I concentration increased whereas GH concentration decreased linearly with increasing concentrate supplementation, irrespective of genetic strain. This indicates that increased supplementation may be facilitating an early recoupling of the somatotropic axis, perhaps via a decreased energy deficit or decreased insulin resistance. This is consistent with the results of Chagas et al. (2009), who reported reduced insulin resistance when pasture-based cows were supplemented with $6 \mathrm{~kg}$ of concentrate $\mathrm{DM} / \mathrm{d}$, compared with those offered 3 or 0 $\mathrm{kg}$ of $\mathrm{DM} / \mathrm{d}$, and the results of Roche et al. (2006), who demonstrated that increased supplementation reduced the time to nadir BCS and increased nadir BCS and postnadir BCS gain.

During early lactation, glucose concentration increased linearly with increasing supplementation, a reflection of greater propionate being produced (precursor for gluconeogenesis) from increased NSC in the diet. In addition, during early lactation, urea concentration decreased linearly with increasing concentrate in the diet. Although DMI was not measured in the present study, substitution (defined as the decrease in pasture intake per kilogram of supplemental feed; Kellaway and Porta, 1993) is a well-known phenomenon (Kellaway and Porta, 1993; Bargo et al., 2003) in grazing systems. In the present study, pasture contained $23.5 \% \mathrm{CP}$, compared with $11.5 \% \mathrm{CP}$ in the concentrate offered (Kolver et al., 2007). Thus, the combined effect of increased concentrate and decreased pasture intake would result in decreased nitrogen intake, decreased rumen ammonia production, and subsequently, decreased plasma urea concentration. This is consistent with the reports of Bargo et al. (2002) and Carruthers and Neil (1997), and may be due to a dilution effect or improved efficiency of dietary nitrogen utilization with supplementation (Bargo et al., 2002).

\section{Genetic Strain $\times$ Diet Interaction}

Extended Lactation. During the extended lactation period, there were genetic strain $\times$ diet interactions for leptin, insulin, and glucose, and these were primarily due to greater concentrations of these hormones and metabolites in the NZ HF receiving $6 \mathrm{~kg}$ of concentrate $\mathrm{DM} /$ d. Greater leptin concentration in the NZ6 treatment is consistent with the greater BCS (Kolver et al., 2007 ) and the fact that leptin (secreted almost exclusively by adipocytes; Zhang et al., 1994; Ahima and Flier, 2000) is representative of overall adiposity (total white adipose tissue mass and adipocyte hypertrophy). Additionally, leptin expression in bovine white adipose tissue explants is upregulated by insulin (Houseknecht et al., 2000); thus, the greater insulin concentration in the NZ6 treatment during the extended lactation period may have contributed to the greater leptin concentration in these animals.

The increased insulin concentration in these animals was most probably a homeostatic response to the greater glucose concentration in animals in the NZ6 treatment. The greater glucose, insulin, and leptin concentrations in the NZ6 treatment, combined with the greater BCS and reduced milk yield in these animals (Kolver et al., 2007), indicate that, during this period, NZ HF offered the greatest amount of concentrate were partitioning nutrients toward body reserves and not milk production. This is supported by the $29 \%$ decrease in annualized milk production in the NZ6 treatment, compared with only a $6 \%$ decrease in the NA6 treatment (Kolver et al., 2007). This strain $\times$ diet interaction is also consistent with the findings of Dillon et al., (2003) and Yan et al. (2006), who reported clear differences between breeds in the partitioning of energy between milk and body reserves when faced with different planes of nutrition, and indicates that nutrient partitioning is a homeorhetic function driven by both genetics and the environment (Friggens and Newbold, 2007). 
In conclusion, the data presented partially explain the physiology regulating the published production and BCS responses in divergent genetic strains of cows (Dillon et al., 2003; Roche et al., 2006; Kolver et al., 2007). Results indicate that the greater milk production and loss of BCS in NA HF during early lactation are consistent with a delayed recoupling of the somatotropic axis and greater insulin resistance in this genetic strain. During the extended lactation period, a genetic strain $\times$ diet interaction was evident, with NZ HF being less efficient at partitioning energy reserves toward milk production in favor of body reserves, particularly when fed $6 \mathrm{~kg}$ of concentrate $\mathrm{DM} / \mathrm{d}$, as indicated by the greater BCS, reduced milk production (Kolver et al., 2007), and greater glucose, insulin, and leptin concentrations in these cows.

\section{ACKNOWLEDGMENTS}

Special thanks go to Penny Aspin for her technical assistance, to the DairyNZ Lye Farm staff, in particular Alan Napper and Bruce Sugar, for their support, and also to Barbara Dow for statistical analysis. This research was funded by NZ Dairy Farmers through DairyNZ Inc., Hamilton, New Zealand.

\section{REFERENCES}

Ahima, R. S., and J. S. Flier. 2000. Leptin. Annu. Rev. Physiol. 62:413-437.

Auldist, M. J., G. O'Brien, D. Cole, K. L. Macmillan, and C. Grainger. 2007. Effects of varying lactation length on milk production capacity of cows in pasture-based dairying systems. J. Dairy Sci. 90:3234-3241.

Bargo, F., L. D. Muller, J. E. Delahoy, and T. W. Cassidy. 2002. Milk response to concentrate supplementation of high producing dairy cows grazing at two pasture allowances. J. Dairy Sci. 85:17771792.

Bargo, F., L. D. Muller, E. S. Kolver, and J. E. Delahoy. 2003. Invited Review: Production and digestion of supplemented dairy cows on pasture. J. Dairy Sci. 86:1-42.

Bauman, D. E. 2000. Regulation of nutrient partitioning during lactation: Homeostasis and homeorhesis revisited. Pages 311-327 in Ruminant Physiology: Digestion, Metabolism and Growth and Reproduction. P. J. Cronje, ed. CAB Publishing, New York, NY.

Bauman, D. E., and W. B. Currie. 1980. Partitioning of nutrients during pregnancy and lactation: A review of mechanisms involving homeostasis and homeorhesis. J. Dairy Sci. 63:1514-1529.

Beerepoot, G. M. M., A. E. Freeman, and J. C. Detilleux. 1991 Effect of season, genetic line, and sire on growth concentrations of somatotropin in serum of Holstein cows in early lactation. J. Dairy Sci. 74:3202-3208.

Blache, D., L. M. Chagas, M. A. Blackberry, P. E. Vercoe, and G. B. Martin. 2000. Metabolic factors affecting the reproductive axis in male sheep. J. Reprod. Fertil. 120:1-11.

Butler, S. T., A. L. Marr, S. H. Pelton, R. P. Radcliff, M. C. Lucy, and W. R. Butler. 2003. Insulin restores GH responsiveness during lactation-induced negative energy balance in dairy cattle: Effects on expression of IGF-I and GH receptor 1A. J. Endocrinol. 176:205-217.

Butler, S. T., L. Shalloo, and J. J. Murphy. 2006. An evaluation of extended lactation as a strategy to alleviate reproductive loss in a seasonal pasture-based system. J. Dairy Sci. 89(Suppl. 1):194 (Abstr.)

Canfield, R. W., and W. R. Butler. 1990. Energy balance and pulsatile LH secretion in early postpartum dairy cattle. Domest. Anim. Endocrinol. 7:323-330.

Carruthers, V. R., and P. G. Neil. 1997. Milk production and ruminal metabolites from cows offered two pasture diets supplemented with non-structural carbohydrate. N. Z. J. Agric. Res. 40:513-521.

Chagas, L. M., J. J. Bass, D. Blache, C. R. Burke, J. K. Kay, D. R. Lindsay, M. C. Lucy, G. B. Martin, S. Meier, F. M. Rhodes, J. R. Roche, W. W. Thatcher, and R. Webb. 2007. New perspectives on the roles of nutrition and metabolic priorities in the sub-fertility of high-producing dairy cows. J. Dairy Sci. 90:4022-4032.

Chagas, L. M., M. C. Lucy, P. J. Back, D. Blache, J. M. Lee, P. J. S. Gore, A. J. Sheahan, and J. R. Roche. 2009. Insulin resistance in divergent strains of Holstein-Friesian dairy cows offered fresh pasture and increasing amounts of concentrate in early lactation. J. Dairy Sci. 92:216-222.

Dillon, P., F. Buckley, P. O'Connor, D. Hegarty, and M. Rath. 2003. A comparison of different dairy cow breeds on a seasonal grass-based system of milk production. 1. Milk production, live weight, body condition score and DM intake. Livest. Prod. Sci. 83:21-34.

Dillon, P., S. Crosse, G. Stakelum, and F. Flynn. 1995. The effect of calving date, and stocking rate on the performance of springcalving cows. Grass Forage Sci. 50:286-299.

Dillon, P., J. R. Roche, L. Shalloo, and B. Horan. 2005. Optimizing financial return from grazing in temperate pastures. Pages 131-147 in Proc. Satellite Workshop XXth Int. Grassl. Congr., Cork, UK. Wageningen Acad. Publ., Wageningen, the Netherlands.

Downing, J. A., J. Joss, P. Connell, and R. J. Scaramuzzi. 1995 Ovulation rate and the concentrations of gonadotrophic and metabolic hormones in ewes fed lupin grain. J. Reprod. Fertil. 103:137-145.

Drackley, J. K. 1999. Biology of dairy cows during the transition period: The final frontier? J. Dairy Sci. 82:2259-2273.

Etherton, T. D., and D. E. Bauman. 1998. Biology of somatotropin in growth and lactation of domestic animals. Physiol. Rev. 78:745761.

Friggens, N. C., and J. R. Newbold. 2007. Towards a biological basis for predicting nutrient partitioning: The dairy cow as an example. Animal 1:87-97.

Gluckman, P. D., J. J. Johnson-Barrett, J. H. Butler, B. W. Edgar, and T. R. Gunn. 1983. Studies of insulin-like growth factor -I and -II by specific radioligand assays in umbilical cord blood. Clin. Endocrinol. (Oxf.) 19:405-413.

Hales, C. N., and P. J. Randle. 1963. Immunoassay of insulin with insulin-antibody precipitate. J. Biochem. 88:137-146.

Harris, B. L., and E. S. Kolver. 2001. Review of Holsteinization of intensive pastoral dairy farming in New Zealand. J. Dairy Sci 84(E Suppl.):E56-E61.

Hart, I. C., J. A. Bines, S. V. Morant, and J. L. Ridley. 1978. Endocrine control of energy metabolism in the cow: Comparison of the levels of hormones (prolactin, growth hormone, insulin, and thyroxine) and metabolites in the plasma of high- and low- yielding cattle at various stages of lactation. J. Endocrinol. 77:333-345.

Horan, B., P. Dillon, P. Faverdin, L. Delaby, F. Buckley, and M. Rath. 2005. The interaction of strain of Holstein-Friesian cows and pasture-based feed systems on milk yield, body weight, and body condition score. J. Dairy Sci. 88:1231-1243.

Houseknecht, K. L., C. P. Portocarrero, S. Ji, R. Lemenager, and M. E. Spurlock. 2000. Growth hormone regulates leptin gene expression in bovine adipose tissue: Correlation with adipose IGF-I expression. J. Endocrinol. 164:51-57.

Kay, J. K., P. W. Aspin, C. V. C. Phyn, J. R. Roche, and E. S. Kolver. 2007. Production and physiological indictors to select cows suitable for extended lactations. Proc. N. Z. Soc. Anim. Prod. $67: 315-319$

Kellaway, R., and S. Porta. 1993. Feeding Concentrate Supplements for Dairy Cows. Dairy Res. Dev. Corp., Melbourne, Australia.

Kim, J. W., R. P. Rhoads, S. S. Block, T. R. Overton, S. J. Frank, and Y. R. Boisclair. 2004. Dairy cows experience selective reduction 
of the hepatic growth hormone receptor during the periparturient period. J. Endocrinol. 181:281-290.

Knight, C. H. 1998. Extended lactation. Pages 30-39 in Hannah Research Institute Yearbook 1998. Hannah Res. Inst., Ayr, UK.

Knight, C. H., M. A. Alamer, A. Sorensen, I. M. Nevison, D. J. Flint, and R. G. Vernon. 2004. Metabolic safety-margins do not differ between cows of high and low genetic merit for milk production. J. Dairy Res. 71:141-153.

Kolver, E. S., J. R. Roche, and P. W. Aspin. 2006. Plasma insulin, growth hormone, and IGF-1 concentrations of Holstein-Friesian cows of divergent genotype offered varying levels of concentrate in early lactation. Proc. N. Z. Soc. Anim. Prod. 66:403-408.

Kolver, E. S., J. R. Roche, C. R. Burke, J. K. Kay, and P. W. Aspin. 2007. Extending lactation in pasture-based dairy cows: I. Genotype and diet effect on milk and reproduction. J. Dairy Sci. 90:55185530 .

Lacy-Hulbert, S. J., E. L. Summers, J. H. Williamson, P. W. Aspin, and E. S. Kolver. 2006. Prevalence of mastitis for cows of different genotypes milked for two consecutive seasons. Proc. N. Z. Soc. Anim. Prod. 66:236-240.

Le Roith, D., C. Bondy, S. Yakar, J. L. Lui, and A. Butler. 2001. The somatomedin hypothesis. Endocr. Rev. 22:53-74.

Lucy, M. C., H. Jiang, and Y. Kobayashi. 2001. Changes in the somatotrophic axis associated with the initiation of lactation. J. Dairy Sci. 84(E Suppl.):E113-E119.

Lucy, M. C., G. A. Verkerk, B. E. Whyte, K. A. Macdonald, L. Burton, R. T. Cursons, J. R. Roche, and C. W. Holmes. 2009. Somatotropic axis components and nutrient partitioning in genetically diverse dairy cows managed under different feed allowances in a pasture system. J. Dairy Sci. 92:526-539.

Macdonald, K. A., B. S. Thorrold, C. B. Glassey, C. W. Holmes, and J. E. Pryce. 2005. Impact of farm management decision rules on the production and profit of different strains of Holstein-Friesian dairy cows. Proc. N. Z. Soc. Anim. Prod. 65:40-45.

McCarthy, S., D. P. Berry, P. Dillion, M. Rath, and B. Horan. 2007. Influence of Holstein-Friesian strain and feed system on body weight and body condition score lactation profiles. J. Dairy Sci. 90:1859-1869.

NRC. 2001. Nutrient Requirements of the Dairy Cattle. 7th rev. ed. Natl. Acad. Press, Washington, DC.

Radcliff, R. P., B. L. McCormack, B. A. Crooker, and M. C. Lucy. 2003. Growth hormone (GH) binding and expression of $\mathrm{GH}$ receptor $1 \mathrm{~A}$ mRNA in hepatic tissue of periparturient dairy cows. J. Dairy Sci. 86:3933-3940.

Radcliff, R. P., B. L. McCormack, D. H. Keisler, B. A. Crooker, and M. C. Lucy. 2006. Partial feed restriction decreases growth hormone receptor 1A mRNA expression in postpartum dairy cows. J. Dairy Sci. 89:611-619.

Rhoads, R. P., J. W. Kim, B. J. Leury, L. H. Baumgard, H. Segoale, S. J. Frank, D. E. Bauman, and Y. R. Boisclair. 2004. Insulin increases the abundance of the growth hormone receptor in liver and adipose tissue of periparturient dairy cows. J. Nutr. 134:1020-1027.

Rhoads, R. P., J. W. Kim, M. E. Van Amburgh, R. A. Ehrhardt, S. J. Frank, and Y. R. Boisclair. 2007. Effect of nutrition on the GH responsiveness of liver and adipose tissue in dairy cows. J. Endocrinol. 195:49-58.

Roche, J. R., D. P. Berry, and E. S. Kolver. 2006. Holstein-Friesian strain and feed effects on milk production, body weight, and body condition score profiles in grazing dairy cows. J. Dairy Sci. 89:3532-3543.

Roche, J. R., P. G. Dillon, C. R. Stockdale, L. H. Baumgard, and M. J. VanBaale. 2004. Relationships among international body condition scoring systems. J. Dairy Sci. 87:3076-3079.

Roche, J. R., K. A. Macdonald, C. R. Burke, J. M. Lee, and D. P. Berry. 2007. Associations among body condition score, body weight, and reproductive performance in seasonal-calving dairy cattle. J. Dairy Sci. 90:376-391.

Verbyla, A. P., B. R. Cullis, M. G. Kenward, and S. J. Welham. 1999. The analysis of designed experiments and longitudinal data by using smoothing splines (with discussion). Appl. Stat. 48:269311.

Weber, W. J., C. R. Wallace, L. B. Hansen, H. Chester-Jones, and B. A. Crooker. 2007. Effects of genetic selection for milk yield on somatotropin, insulin like growth factor-I and placental lactogen in Holstein cows. J. Dairy Sci. 90:3314-3325.

Yan, T., C. S. Mayne, T. W. J. Keady, and R. E. Agnew. 2006. Effects of dairy cows genotype with two planes of nutrition on energy partitioning between milk and body tissue. J. Dairy Sci. 89:10311042.

Zhang, Y., R. Proenca, M. Maffei, M. Barone, L. Leopold, and J. M. Friedman. 1994. Positional cloning of the mouse obese gene and its human homologue. Nature 372:425-432. 